
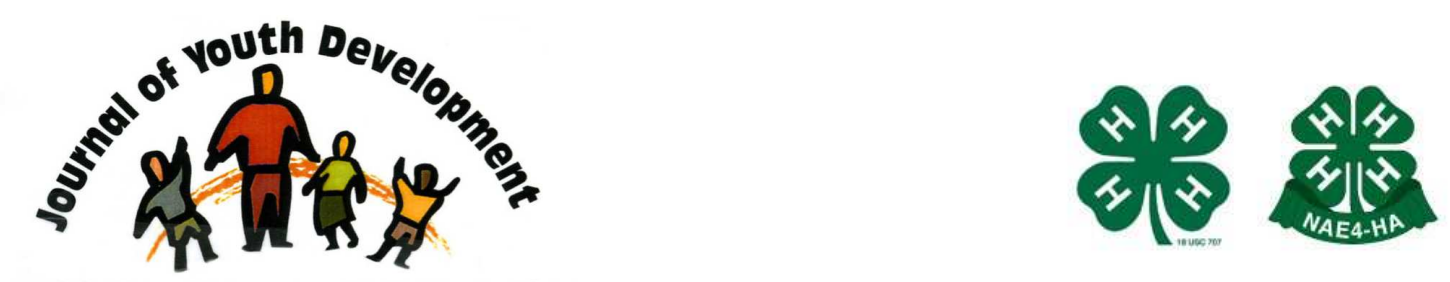

Bridging Research \& Practice

\title{
Using an Active Learning Approach (the 4-H model) to Stimulate Social Change: Youth and Community Development in the Republic of Kyrgyzstan
}

Timothy K. Kock

Department of Agricultural Education, Communications \& Leadership

College of Agricultural Sciences \& Natural Resources

Oklahoma State University

Stillwater, OK

tim.kock@okstate.edu 


\title{
Using an Active Learning Approach (the 4-H model) to Stimulate Social Change: Youth and Community Development in the Republic of Kyrgyzstan
}

Timothy K. Kock

Oklahoma State University

\begin{abstract}
As Kyrgyzstan recovers from the collapse of the Soviet Union, the youth of this Newly Independent State (NIS) face troubling times. Poverty has become all to familiar throughout the country; its people, including youth, are losing hope and question their ability to be productive members of society (Lines \& Kock, 2004). Kyrgyzstan's future leaders - like all nations - are found among its youth of today. Therefore, it behooves the government and citizens of Kyrgyzstan to develop youth centers designed to enhance the skills young people need to succeed now and in the future.

This paper describes a program designed to teach Kyrgyz youth and adults teamwork, and civic responsibility through experiential learning activities. The paper outlines the steps taken and results derived from the hands-on trainings provided to the participants in one location in Kyrgyzstan. Findings from this study may have implications for other international youth development projects.
\end{abstract}

\section{Introduction}

Central Asian youth are clearly disadvantaged in many aspects of life compared to their parents' generation (Silova, Johnson, \& Heyneman, 2007). As Kyrgyzstan recovers from the collapse of the Soviet Union, the youth of this Newly Independent State (NIS) face troubling times. Poverty has become all to familiar throughout the country, it's people, including youth, are losing hope and question their ability to be productive members of society (Lines \& Kock, 2004).

Kyrgyzstan's future leaders - like all nations - are found among its youth of today. As asserted by the United Nations Children's Fund (UNICEF) organization, "adolescents today are the men and women of tomorrow" (UNICEF, 2005). Therefore, it behooves the government and citizens of Kyrgyzstan to develop youth centers designed to enhance the skills young people need to succeed now and in the future. 
As is the situation in most post-Soviet countries, public investment in Kyrgyz youth and more particularly youth in rural settings, have been marginalized during the on-going transition. The new political, social, and economic paradigm of democracy, personal responsibility and freemarket economics has left youth development behind (Lines \& Kock, 2004). The years of communism and precarious transition thereafter have strapped the NIS states with social and economic challenges (Babajanian, Freizer, \& Stevens, 2005). The nation needs to invest in its' rural youth, not just its' urban youth, through educational opportunities and centers that foster youth adult partnerships (Gregoire, 2004). Young people in rural communities need meaningful educational experiences that will enhance their capabilities to work together to pursue their own interests and that of their communities (Peters, 2002).

Community organizations in rural or disadvantaged regions that provide development activities play a vital role in social change (Jackson \& Boateng, 2006). These youth centers would promote social development at the grassroots level. Work at this level has become a priority in the developing world (Earle, 2005). Earle also suggests that much of this has to do with changing global politics and the realignment of development. Many developing countries lack the financial and human recourses to promote rural community development. Therefore, collective self-help has gained popularity as a way to address the needs of poor communities (Earle, 2005).

\section{Problem Statement}

In the Soviet Union, any independent civil organization was considered "illegal or semi legal" and was a threat to the nation's political system (Babajanian, 2005). Earl (2005) supports this by stating that in South Kyrgyzstan collective voluntary mobilization was fairly rare, communities depended on government for support. However, after the collapse of the Soviet system, many Kyrgyz people, including youth, had very little use for government programs; they were preoccupied with providing for themselves and their families (Eurasianet, 2005). Therefore, the need to develop community-based youth educational programs that are driven by local community members and not part of the government became a priority. These organizations became an intermediary between the state and private life (Banajanian, Freizer, \& Stevens, 2005).

Countries that do not educate their youth can not achieve sustainable development (UNICEF, 2005). One way to address this need is the development of community youth centers managed by youth and adults that provide leadership opportunities to community members. However, centers of this type could be perceived as undermining the traditional Kyrgyzstan practices of the exclusion of women and young people in the decision-making process for a social unit (Banajanian, Freizer, \& Stevens, 2005). Community members (elders) and faculty of the College of Mining in Kyzyl-Kiya, Kyrgyzstan expressed interest to local Agricultural Cooperative Development International/Volunteers in Overseas Cooperative Assistance, (ACDI/VOCA) Community Action Investment Program (CAIP) employees about building a community-based center for local youth. Earle (2005) pointed out that dialogue with community members before projects are started will add to the probability of successful outcomes. 


\section{Purpose of the Program}

Before monies would be spent (funded by the United States Agency for International Development [USAID]) on the construction and refurbishing of the community center, located at the College of Mining, four issues needed to be addressed:

1) community members needed to learn to work together as a team instead of individuals;

2) the center's purpose (vision and mission statement) needed to be written;

3) an organizational hierarchy or board of officers needed to be developed; and,

4) a set of working by-laws or "rules of the game" (Huebner, 1998) for board members to follow needed to be created.

The management team of the ACDI/VOCA CAIP program perceived these four issues as important for the sustainability of community youth centers.

ACDI/VOCA staff provided group facilitation and team-building trainings to local youth and adults who expressed an interest in the design and management of the proposed center. The trainings were designed to create an atmosphere of teamwork, leadership, and character development. For young people, leadership includes opportunities for caring relationships with adults and community engagement (Jacob, Wertlieb, \& Lerner, 2003).

To accomplish the team-building issue, experiential learning methodology, such as 'Challenge' activities and character-development education was implemented to build relationships, based on trust and respect, between participants through basic hands-on activities. The "mistrust" the volunteers (participants) demonstrated towards belonging to community organizations and each other was a by-product of past Soviet rule according to Banajanian (2005).

This is not new phenomenon; historically other countries including the United States, have dealt with issues of that nature. A century ago, rural Americans were struggling with some of those very issues. For example, under the direction of President Theodore Roosevelt the Commission on Country Life stated: "It is the greatest consequence that people of the open country should learn to work together, not only for the purpose of forwarding their economic interests and competing with other men who are organizing, but also to develop themselves and to establish an effective community spirit" (Commission on Country Life, 1909/1911 p. 128).

Once volunteers (participants) had completed four days of "Experiential Learning" and character education training encompassing teamwork, leadership, and responsibility, work on the second, third and fourth issues (i.e., writing a vision and mission statement, officers, and by-laws) began.

\section{Data Sources and Methods}

In the fall/winter of 2004, ACDI/VOCA implemented a community development project in the rural community of Kyzyl Kiya, Kyrgyzstan. The community of Kyzyl Kiya provided 25 citizens who expressed interest in the development of a youth center in their community. The participants, 16 women and 9 males, ranging in age from 17 to 39, had some interaction with each other through school or college but they showed very little desire to work together. 
A "process approach" was used to build on the skills the participants needed for the design of the infrastructure of the center (Earle, 2005). Earle stated that a process approach empowers people and social benefits are placed before installation of infrastructure. Observations by the researcher during class trainings (Smith \& Lincoln, 1984) and creation of the center's vision and mission statement, board officers, and by-laws served as source of data for qualitative evaluation of project.

At no time during the training was a participant mandated to participate in any activities; participation was completely voluntary (Washington State University, 2000). The majority of participants were involved in all activities. Only one chose not to participate in an activity (i.e., the trust walk). That individual did not feel comfortable being blindfolded. Because of the program's focus on participants' experiences and educational outcomes, a narrative evaluation was used to explain the qualitative research results (Short, 1991). According to Short, John Elliot defined this approach as action research: "the study of a social situation with a view to improving the quality of the action within it" (p. 311). McKernan restated this kind of reflective inquiry as "practical action research" (Short, p. 312).

\section{Findings and Conclusions}

At the completion of four days of training, the first goal, creation of a vision and mission statement for the Center, was started. Through classroom discussion, it was concluded that more than $70 \%$ percent of the participants had never heard of a vision or mission statement, and none had ever had the opportunity to create one. Therefore, a brief outline or discussion on the purpose of each took place. Once the participants gained a better understanding of how these statements would "frame" the purpose of the youth center, focused group dialog began. The first aspect of this part of the project was the creation of a vision statement. The researcher believed that by implementing a collective decision-making process (Toness, 2001), participants could create a vision of what they hoped the center would do for the community, and then the mission statement would come more easily.

Through a day of group discussion and student interaction, concepts started to surface and participants began to build on one another's ideas (Bruening, Lopez, McCormick, \& Dominguez, 2002). At the end of the third day, a vision statement was completed. The next step was to develop a mission statement for the center. By this time, participants were becoming more comfortable with each other. This was noticed through their body gestures, the fact that participants began sitting in different seats, and because several participants began to lead discussions about the mission statement.

After two days of consensus building and numerous revisions, the Center's mission statement was completed. Following further discussion, participants voted to combine the vision and mission statements into one document. According to Jackson and Boateng (2006), that indicated an understanding of democracy and a sign of "social change" (Goal 1). The participants stated that they believed a single document would work best for the Center. This combining of the documents led the researcher to hypothesize that community ownership of the Center was taking shape. 
Goal 1. Combined Vision/Mission Statement of Kyzyl Kiya Community Youth Center

"This youth center was established to help develop youth to be qualified and competent citizens of Kyrgyzstan through information, education and the promotion of healthy living."

Participants spent the next five days working on by-laws that would serve as rules for governing the Center. The foundation of any organization is a constitution and by-laws (Jordan, 1999). Through group discussions concerning what type of a management structure would best serve the Center, participants decided that there should be a "governing board" system modeled after the U.S. 4-H Council approach. This consisted of a president, vice-president, secretary, treasurer and three ex-officio members consisting of an elected government official, international non-governmental organization (NGO) representative, and a college of mining representative.

During the next step in the process, participants worked through voting issues, length of board members' terms, and their duties. Unfortunately, the current Kyrgyz government was perceived as corrupt (Eurasianet, 2005) and provided poor examples and little valuable guidance as to the functions of governing board. After a brief discussion about roles and responsibilities of American 4-H volunteer councils, participants began to describe the anticipated functions of each board member for the proposed Center (Goal 2).

Goal 2. Board Members' Titles and Responsibilities

a) President: This officer will run board meetings, give direction to youth center manager (as described by board) and be spokesperson for the youth center/ NGO.

b) Vice President: This officer will preside during board meetings when president is absent. The main function of this officer is to serve as manager of the youth center, providing direction to coordinators (e.g., education and sports) as directed from the board.

c) Secretary: This officer is responsible for minutes of meetings, any correspondence to board and communication to members and the public.

d) Treasurer: This officer is accountable for funds generated by the youth center/NGO; for any money to be spent, it must be voted on by the board. A receipt book or other accounting program will be used. The expenditures and funds must have been approved by the board and a receipt must have two board members' signatures: President and Treasurer or that of Vice President when either of the other officers is unavailable.

By-laws or governing rules for voting was the final step or third goal in development of a board for the Youth Center. Some participants expressed concerns about how to create a system that would treat each member equally and who could be a member of the board. Through volunteers' participation in all levels of the decision-making process (Toness, 2001), participants designed rules for elections and voting rights of board members (Goal 3).

\section{Goal 3. By-Laws for Youth Center Board}

a) Board members will serve a one or two year term. Selection of members serving a one-year term will be decided by random drawing after second year of operation. (For the first two years, the board will remain the same; after the second year, the rotational terms will take effect.) 
b) Members of the board may serve two consecutive terms then must sit out for a period of one year before running for the board again. If a board seat becomes vacant that opening will be filled (through voting) for the remainder of that term.

c) Eligible candidates for the board will be youth members of the Youth Center or the parents of those youth. Winning seats to the board will be candidate(s) with most votes cast by Youth Center members and their parents. Candidates seeking election to the board will be publicized in the Youth Center's newsletter.

d) There will be 12 members of the board excluding the three ex-officio members.

e) Election to the board will be held in January of each year.

f) All issues decided by the board must be voted on by the Board members present at any meeting. For an issue to pass, it must receive a simple majority of the votes (51\%). By-law changes: Changes to the By-Laws may be made only at first meeting of the new calendar year and $90 \%$ (11 members) of voting board members must be present. The change must receive $75 \%$ ( 9 members) of the board members' votes.

These activities enhanced participants' knowledge and understanding concerning community empowerment and civic responsibility as it related to building capacity in their own community. By youth working through this type of service-learning activity, the likelihood of them becoming community leaders who take on the responsibility for solving community problems should increase (Des Marais, Yang, \& Faranehkia, 2000).

\section{Implications, Discussion and Educational Importance}

As the post-Soviet system changes and Newly Independent States (NIS) move toward their communities being governed democratically, the need for youth and adult development programs that instill a spirit of volunteerism and service increases. This was true a century ago in the United States when Cooperative Extension was authorized by Congress through the passing of the 1914 Smith-Lever Act. Extension served as the driving force to usher in new ideas that helped rural people. This is also true today. By teaching citizens of foreign countries the importance of the development of social organizations that lead to positive change, those citizens may motivate other countries to move closer to a democratic process.

For many years, the United States Agency for International Development (USAID) and the United States Department of Agriculture Foreign Agricultural Service (USDA/FAS) have sought out universities for consultants. More specifically, they have looked to land-grant universities and the Cooperative Extension Service (Duffy, Toness \& Christiansen, 1998; Finley \& Price, 1994) when filling positions for development projects world-wide. Now with the renewed motivation from the United States Department of Agriculture and the United States Agency for International Development (USDA, 2007) for Extension faculty to work in foreign countries, the processes mentioned in this paper may help other Extension professionals working on international assignments design programs that may further the democratic process and help people from other countries reach their desired outcomes of social change.

\section{Recommendations}

As more community-driven youth and adult programs are implemented in Kyrgyzstan, other former post-Soviet countries, and the world, people in those countries may become more aware of the world as a global society. The purpose of community organizations is to build 
relationships among groups and individuals that enhance the ability of a society to work together in creating organizations that benefit the common good of members in that community (Sanderson, \& Polson, 1939). According to Banajanian, Freizer and Stevens (2005), historically, there have been community self-help groups termed ashara (in Kyrgyzstan) throughout Central Asia that still have meaning today. The approach described in this study may have complemented that social construct.

It is important for young people to understand the process in which they live and identify with cultural and social environments (Banajanian, 2005). Through this process, youth and adult participants should have gained the social-cultural tools necessary to become a vital and contributing voice in their communities. Success of the development of this community program should enhance the confidence of community members to organize other projects (Banajanian, Freizer, \& Stevens, 2005) that would contribute to the development and welfare of their local societies. However, the ultimate question becomes whether revitalized youth educational centers can create sustainable social cohesion and human development throughout Kyrgyzstan and the broader region (Silova, Johnson, \& Heyneman, 2007). Providing participants the opportunity to work through differences and their willingness to democratically "vote" on issues indicated the effectiveness of the youth center development project.

This study may provide others working in community development and democracy building a roadmap for developing sustainable community-driven programs that benefit the people living in other parts of the world. By following the steps explained in this study, and involving members of the community where they are working the opportunity to work through the process. Development workers may emulate the outcome of this community-driven project. However, it is important to remember there is no cookie-cutter formula that will work in every community, development workers need to be flexible and do what is needed in the community they are serving.

\section{References}

Banajanian, B. (2005). Civic participation in post-Soviet Armenia. Central Asian Survey, 24 (3), 261-279.

Banajanian, B., Freizer, S., \& Stevens, D. (2005). Introduction: Civil society in Central Asia and the Caucasus. Central Asian Survey, 24 (3), 209-224.

Bruening, T., Lopez, J., McCormick, D., \& Dominguez, D. (2002). Active learning: The impact on students participating in an extended field trip to Puerto Rico, Journal of Agricultural Education, 43 (4), 66-79. Retrieved March 17, 2007 from http://pubs.aged.tamu.edu/jae/pdf/vol43/43-04$\underline{67}$

Commission On Country Life. (1909/1911). Report of the country life commission. (p.128). New York: Sturgis and Walton.

Des Marais, J., Yang, Y., \& Farzanehkia, F. (2000). Service-learning leadership development for youths. Phi Delta Kappan, 81 (9) 2-5. Retrieved January 18, 2007, from http://www.web.ebscohost.com/ehost/detail 
Duffy, S., Toness, A., \& Christiansen, J. (1998). Internationalization of land grant university curriculum for sustainable development. Journal of International Agricultural and Extension Education, 5(2), 43-50.

Earle, L. (2005). Community development, 'tradition' and the civil society strengthening agenda in Central Asia. Central Asia Survey, 24 (3), 245-260.

Eruasianet.org. (2005). Kyrgyzstan's revolution: Be careful what you wish for. Retrieved January 15, 2007, from http://www.eurasianet.org/departments/insight/articles/eav032505.shtml

Finley, E., \& Price, R. (1994). International agriculture. (pp. 165-181). New York: Albany, Delmar Publishing.

Gregoire, H. (2004). Gathering wisdom from 4-H youth development clubs. Journal of Extension, [On-Line] 42 (3). Available at: http://www.joe.org/joe/2004june/a5.shtml.

Huebner, A. (1998). Examining "Empowerment": A how-to guide for the youth development professional. Journal of Extension, [On-Line] 36 (6). Available at:

http://www.joe.org/joe/1998december

Jackson, D., \& Boateng, J. (2006). Ten recommendations for positive international extension experience. Journal of International Agricultural and Extension Education. 282-288.

Proceedings, $22^{\text {nd }}$ Annual Conference.

Jacobs, F., Wertlieb, D., \& Lerner, R. (2003). Handbook of applied developmental science, promoting positive child, adolescent, and family development through research, policies and programs Volume 2. Eliot-Person Department of Child Development, Tufts University. Thousand Oaks, CA, Sage Publications.

Jordan, J. (1999). Designing a 4-H club constitution and by-laws. The Ohio State University, Extension Fact Sheet, No. 4-H-025-99.

Lines, A., \& Kock, T. (2004). Georgian rural development (4-H \& FFG): Enhancement of leadership and farm production and marketing skills. Internal Document, Georgian Agriculture and Education Development Fund. Tbilisi, Republic of Georgia.

MapCruzin.com. (2010). Map of Kyrgyzstan. Retrieved June 23, 2010, from http://www.mapcruzin.com/free-maps-kyrgyzstan/kyrgyzstan sm 2008.gif

Peters, S. (2002). Rousing the people of the land: The roots of the educational organizing tradition in extension work. Journal of Extension, [On-Line] 40 (3). Available at: http://www.joe.org/joe/2002june

Sanderson, D., \& Polson, R. (1939). Rural community organization. New York: John Wiley \& Sons.

Short, E. (Editor). (1991). Forms of Curriculum Inquiry. New York: Albany, State University of New York Press, (pp. 310-312). 
Silova, I., Johnson, M., \& Heyneman, S. (2007). Education and the crisis of social cohesion in Azerbaijan and Central Asia. Comparative Educational Review, 51 (14), 159-170.

Smith, M., \& Lincoln, Y. (1984). Another kind of evaluation. Journal of Extension, [On-Line] 22 (6). Available at: http://www.joe.org/joe/1984november

Toness, A. (2001). The potential of participatory rural appraisal (PRA) approaches and methods for agricultural extension and development in the $21^{\text {st }}$ century. Journal of International Agricultural and Extension Education, 8(1), 25-37.

UNICEF, Bolivia. (2005). The children: Adolescence. Publication 1542, Retrieved January 15, 2007, from www.unicef.org/bolivia/children 1542.html

United States Department of Agriculture. (2007). Development resources and disaster assistance: Afghanistan. 4-24. Retrieved September 22, 2007 from http://www.fas.usda.gov/icd/drd/afghanistan.asp

Washington State University. (2000). Bellingham challenge program. Retrieved January 15, 2007, from http://www.wsu.edu/4-H/challenge/WWW consent release.doc

(C) Copyright of Journal of Youth Development $~$ Bridging Research and Practice. Content may not be copied or emailed to multiple sites or posted to a listserv without copyright holder's express written permission. However, users may print, download or email articles for individual use. 